\title{
Acrocarpospora gen. nov., a new genus of the order Actinomycetales
}

\author{
Tomohiko Tamura, ${ }^{1}$ Shin-ichi Suzuki ${ }^{2}$ and Kazunori Hatano ${ }^{1}$
}

\footnotetext{
1 Institute for Fermentation, Osaka, 17-85 Jusohonmachi 2-chome, Yodogawa-ku, Osaka 5328686, Japan

2 Basic Technology Department, Discovery Research Laboratories, Tanabe Seiyaku Co. Ltd, 2-50, Kawagishi 2-chome, Toda-shi, Saitama 335-8505, Japan
}

Author for correspondence: Tomohiko Tamura. Tel: +8166300 6555. Fax: +81663006814. e-mail: k90089@simail.ne.jp

\begin{abstract}
The taxonomic position of two actinomycete strains isolated from soil was studied. The isolates contained glutamic acid, alanine and mesodiaminopimelic acid as cell-wall amino acids and menaquinone $\mathrm{MK}-\mathbf{9}\left(\mathrm{H}_{4}\right)$ and madurose in the whole-cell hydrolysate. Phylogenetic analysis revealed that the isolates belonged to the family Streptosporangiaceae, but not to any known genus, and formed a monophyletic cluster with Streptosporangium corrugatum. On the basis of morphological characteristics, phylogenetic analysis and DNA-DNA hybridization, the name Acrocarpospora gen. nov. is proposed for a new genus containing the isolates and Streptosporangium corrugatum, and Acrocarpospora pleiomorpha sp. nov. R-31' (= IFO 16267'), Acrocarpospora macrocephala sp. nov. R-55 (= IFO 16266') and Acrocarpospora corrugata comb. nov. IFO $13972^{\top}$ are described.
\end{abstract}

Keywords: Acrocarpospora gen. nov., Streptosporangium corrugatum, family Streptosporangiaceae, 16S rDNA

\section{INTRODUCTION}

The family Streptosporangiaceae (Stackebrandt et al., 1997) includes the following genera: Microtetraspora (Zhang et al., 1998), Microbispora (Zhang et al., 1998), Streptosporangium (Stackebrandt et al., 1994), Herbidospora (Kudo et al., 1993), Planomonospora (Thiemann et al., 1967), Planobispora (Thiemann \& Beretta, 1968), Planotetraspora (Runmao et al., 1993) and Nonomuraea (Zhang et al., 1998). Most members of the family have cell wall type III, whole-cell sugar pattern $\mathrm{B} / \mathrm{C}$, fatty acid pattern $3 \mathrm{c}$, major menaquinone MK-9 $\left(\mathrm{H}_{0}, \mathrm{H}_{2}, \mathrm{H}_{4}, \mathrm{H}_{6}\right)$ and phospholipid type IV. Each genus has distinguishable morphology with the exception of Microtetraspora and Nonomuraea.

The genus Streptosporangium develops stable, branched mycelium and produces globose sporangia (usually $10 \mu \mathrm{m}$ in diameter) on aerial mycelium. Sporangiospores are formed by septation of coiled, unbranched hyphae within the sporangium. However, Streptosporangium viridogriseum subsp. viridogriseum (Okuda et al., 1966), Streptosporangium viridogriseum subsp. kofuense (Nonomura \& Ohara, 1969), Streptosporangium albidum (Furumai et al., 1968), Strepto-

The GenBank accession numbers for the $16 \mathrm{~S}$ rRNA gene sequences of Acrocarpospora pleiomorpha sp. nov. strain $\mathrm{R}-31^{\top}$ and Acrocarpospora macrocephala sp. nov. strain $\mathrm{R}-55^{\top}$ are $\mathrm{AB} 006174$ and $\mathrm{AB} 025318$. sporangium viridialbum (Nonomura \& Ohara, 1960), Streptosporangium claviforme (Petrolini et al., 1992) and Streptosporangium corrugatum (Williams \& Sharples, 1976) differ from the ordinary members of the genus Streptosporangium in the morphological properties of sporangia detected by scanning electron microscopy, electrophoretic mobility of ribosomal protein AT-L30 (Ochi \& Miyadoh, 1992), 16S rDNA (Kemmerling et al., 1993; Ward-Rainey et al., 1996) and 5S rRNA (Kudo et al., 1993). Stackebrandt et al. (1994) transferred $S$. viridogriseum subsp. viridogriseum, S. viridogriseum subsp. kofuense and $S$. albidum to the new genus Kutzneria as Kutzneria viridogrisea, Kutzneria kofuensis and Kutzneria albida on the basis of chemotaxonomic characteristics.

Two actinomycete strains that formed club-shaped or spherical structures at the heads of the aerial mycelia were isolated from soil. They contained menaquinone MK-9 $\left(\mathrm{H}_{4}\right)$, phospholipid type IV, meso-diaminopimelic acid as a cell-wall diamino acid and madurose in the whole-cell hydrolysate. Phylogenetic analysis based on 16S rDNA sequences indicated that the isolates were distinct from previously described genera and were closely related to S. corrugatum (Williams \& Sharples, 1976).

In this paper, we describe the characterization and classification of strains $\mathrm{R}-31^{\mathrm{T}}$ and $\mathrm{R}-55^{\mathrm{T}}$ and $S$. corrugatum and we propose the creation of Acrocar- 

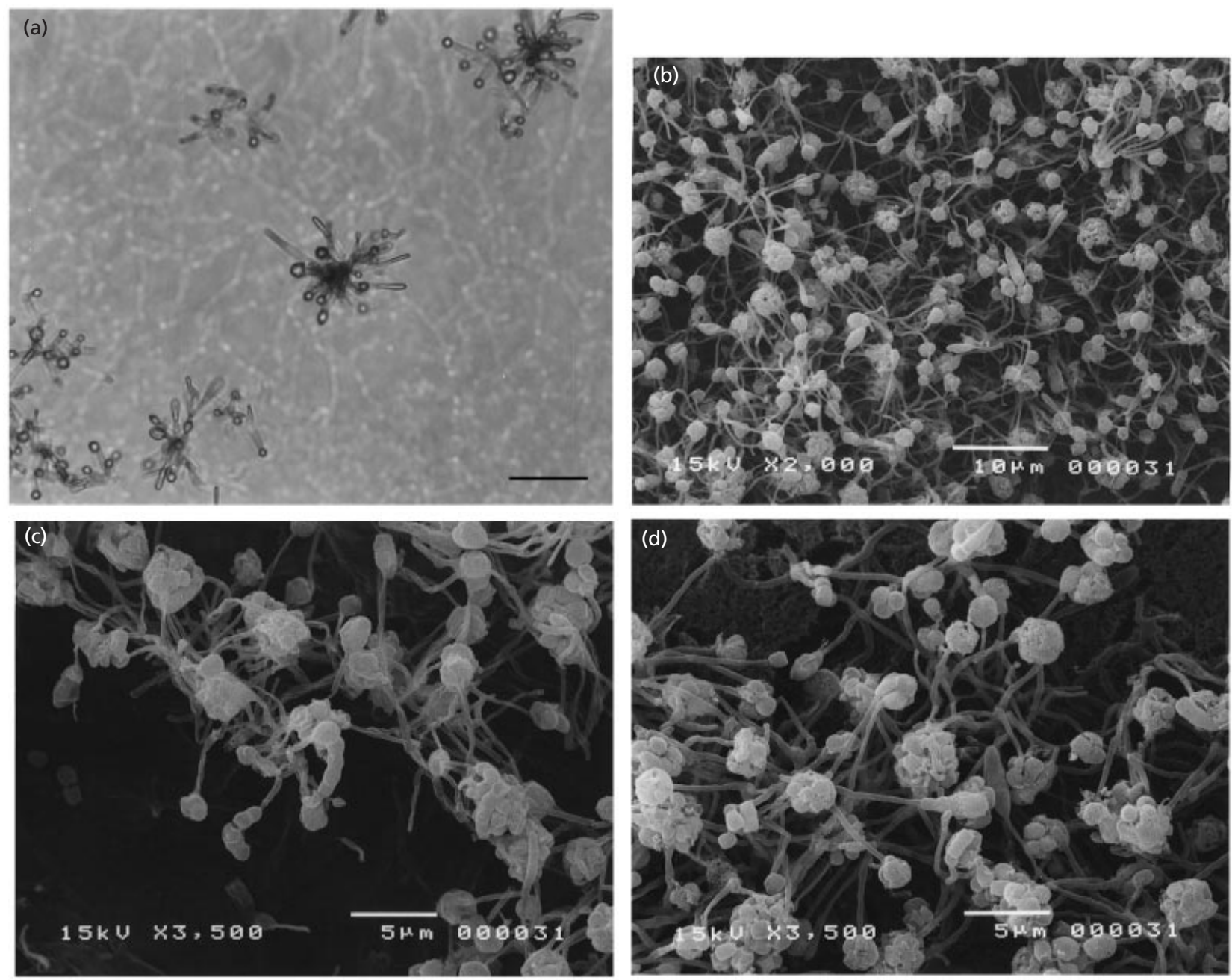

Fig. 1. Light micrograph (a) and scanning electron micrographs (b, $c$ and d) of strain $R-31^{\top}$ grown on $H V$ agar for $14 d$ at $28^{\circ} \mathrm{C}$. Bars, $50 \mu \mathrm{m}(\mathrm{a})$ and $10 \mu \mathrm{m}(\mathrm{b}-\mathrm{d})$.

pospora gen. nov., with Acrocarpospora pleiomorpha sp. nov. for R-31 $1^{\mathrm{T}}$ (=IFO $\left.16267^{\mathrm{T}}\right)$, Acrocarpospora macrocephala sp. nov. for R-55 $\left(=\mathrm{IFO} 16266^{\mathrm{T}}\right)$ and Acrocarpospora corrugata comb. nov. for S. corrugatum (type strain IFO $13972^{\mathrm{T}}$ )

\section{METHODS}

Micro-organisms and culture conditions. Strain R- $31^{\mathrm{T}}$ was isolated from soil in Louisiana, USA, and strain $\mathrm{R}-55^{\mathrm{T}}$ was isolated from soil in Saitama prefecture, Japan. S. corrugatum IFO $13972^{\mathrm{T}}$ was used.

Morphological and physiological characteristics. Cultures grown on HV agar and yeast extract/starch agar for 3-14 d at $28{ }^{\circ} \mathrm{C}$ were observed with a light microscope and a scanning electron microscope (model JSM-5400; JEOL). Samples for scanning electron microscopy were prepared by cutting a block from an agar plate containing the strain, fixing the block in osmium tetroxide vapour at room temperature for $4 \mathrm{~h}$, dehydrating cells through freeze-drying and sputter-coating the preparation with palladium under vacuum.

Motility was observed with a light microscope using cells grown on $\mathrm{HV}$ agar for $7-10 \mathrm{~d}$ at $28^{\circ} \mathrm{C}$ and then incubated at $28^{\circ} \mathrm{C}$ for $30-60 \mathrm{~min}$ in sterile water.

Cultural characteristics on the International Streptomyces project (ISP) media (Shirling \& Gottlieb, 1966) and nutrient agar (Difco Laboratories) were recorded after $14 \mathrm{~d}$ incubation at $28^{\circ} \mathrm{C}$. Colours are described in common terminology, but exact colours were determined by comparison with colour chips of a mycological colour chart (Rayner, 1970).

ISP medium 9 was used as the basal medium for utilization of sugars. Inorganic salts/starch agar (ISP medium 4) was used for determined of starch hydrolysis. Growth temperature was determined on yeast extract/starch agar. Calcium malate medium (1\% calcium malate, $0.05 \%$ $\mathrm{NH}_{4} \mathrm{Cl}, 0.05 \% \mathrm{~K}_{2} \mathrm{HPO}_{4}, 1 \cdot 8 \%$ agar, $\mathrm{pH} \mathrm{7.0)}$ was used for the determination of solubilization of calcium malate. ISP medium 8 was used for the determination of nitrate 

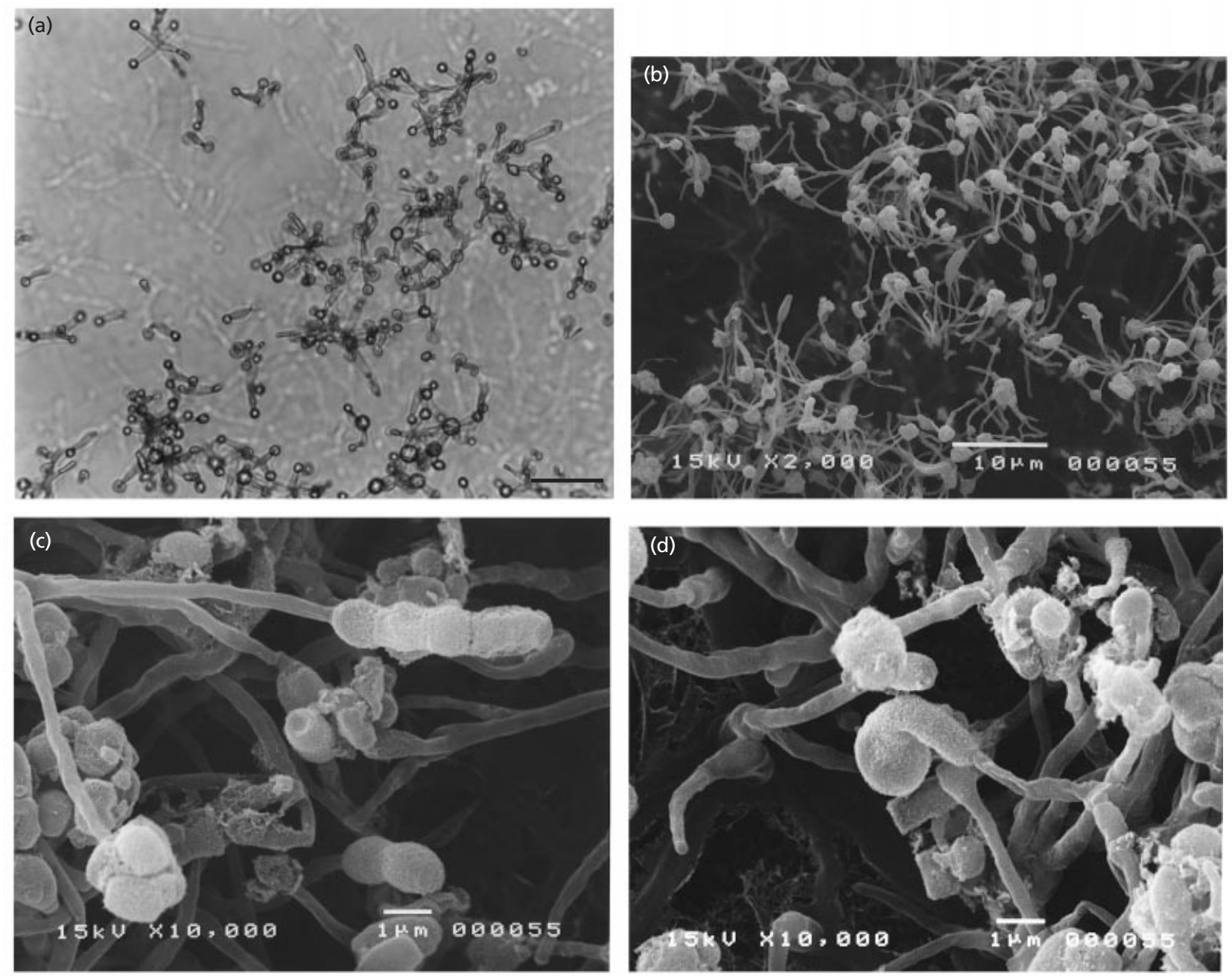

Fig. 2. Light micrograph (a) and scanning electron micrographs (b, $c$ and d) of strain R-55 grown on HV agar for $14 \mathrm{~d}$ at $28^{\circ} \mathrm{C}$. Bars, $50 \mu \mathrm{m}(\mathrm{a})$ and $10 \mu \mathrm{m}(\mathrm{b}-\mathrm{d})$.

reduction. Gelatin medium $(20 \%$ gelatin, $\mathrm{pH} 7 \cdot 0)$ and glucose/peptone/gelatin medium (2\% glucose, $0.5 \%$ peptone and $20 \%$ gelatin, $\mathrm{pH} 7 \cdot 0$ ) were used for the determination of gelatin liquefaction. Skimmed milk $(10 \%$; Difco Laboratories) was used for determination of milk peptonization.

Analysis of chemotaxonomic characteristics. The analysis of whole-cell sugar composition, amino acid composition of the cell wall, menaquinone composition, cellular fatty acid composition, isomers of diaminopimelic acid, acyl type of peptidoglycan, mycolic acid and DNA base composition was performed as described previously (Tamura et al., 1994).

Preparation of DNA and $\mathbf{G}+\mathbf{C}$ content of DNA. Genomic DNA was prepared according to the method of Saito \& Miura (1963) with modifications. The $\mathrm{G}+\mathrm{C}$ content of DNA was determined by the method of Mesbah et al. (1989) after treatment with $\mathrm{P} 1$ nuclease and alkaline phosphatase and with HPLC using a Shimadzu LC-6AD apparatus equipped with a Cosmosil 5C18-AR column $(4 \cdot 6 \times 150 \mathrm{~mm}$; Nacalai Tesque).
PCR amplification and sequencing of 16S rDNA. 16S rDNA was amplified by PCR (Saiki et al., 1988) using protocols described previously (Tamura et al., 1998). The PCR products were sequenced directly using protocols described previously (Tamura et al., 1998). The products were analysed with a Pharmacia ALF DNA Sequencer II according to the manufacturer's protocol.

Phylogenetic analysis. 16S rDNA sequences of the strains and reference organisms were aligned against that of Streptomyces ambofaciens (Pernodet et al., 1989). The CLUSTAL W software version 1.7 (Thompson et al., 1994) was used to generate evolutionary distances (the $K_{\text {nuc }}$ value of Kimura, 1980), similarity values, neighbour-joining analysis (Saitou \& Nei, 1987) from $K_{\text {nuc }}$ values and bootstrap resampling method of Felsenstein (1985) with 1000 replicates for evaluation of the topology of the phylogenetic tree. NJPLOT (Perrière \& Gouy, 1996) was used for plotting the phylogenetic tree.

Measurement of DNA similarity. The microplatehybridization method developed by Ezaki et al. $(1988,1989)$ 
with minor modifications (Tamura et al., 1999) was applied to determine DNA similarity.

\section{RESULTS}

\section{Morphological observations}

The isolates were Gram-positive, non-acid-fast and aerobic organisms with branched hyphae. A nonfragmenting substrate mycelium was formed. Morphological observations by light microscope of a 14-dold culture grown on HV agar revealed the presence of a few club-shaped and many spherical structures at the pointed heads of the aerial hyphae (Figs 1a and 2a). Observation by scanning electron microscope indicated that the structures were variable in size: spherical $(2.0-5.0 \mu \mathrm{m})$ or club-shaped $(0.7-1.5 \times 3.5-8.0 \mu \mathrm{m})$ (Figs $1 \mathrm{~b}-\mathrm{d}$ and $2 \mathrm{~b}-\mathrm{d}$ ). Both structures appeared to be covered by a wrinkled envelope and the undulations of the envelope suggested that spores might be present within (Figs $1 \mathrm{c}$ and d, 2c and d). The spores were oval

Table 1. Phenotypic characteristics of isolates $R-31^{\top}$ and $\mathrm{R}-55^{\top}$

Characteristics are scored as negative $(-)$, positive $(+)$ or strongly positive $(++)$.

\begin{tabular}{|c|c|c|}
\hline Characteristic & $\mathbf{R}-31^{\mathrm{T}}$ & $\mathbf{R}-\mathbf{5 5} \mathbf{5}^{\mathrm{T}}$ \\
\hline \multicolumn{3}{|l|}{ Utilization of: } \\
\hline Glucose & ++ & ++ \\
\hline D-Xylose & - & - \\
\hline Inositol & - & - \\
\hline Sucrose & - & ++ \\
\hline Raffinose & ++ & + \\
\hline Rhamnose & + & + \\
\hline D-Mannitol & ++ & ++ \\
\hline D-Fructose & - & - \\
\hline L-Arabinose & - & - \\
\hline \multicolumn{3}{|l|}{ Melanin formation on: } \\
\hline ISP medium 1 & - & - \\
\hline ISP medium 6 & - & - \\
\hline ISP medium 7 & - & - \\
\hline Gelatin liquefaction & - & - \\
\hline Peptonization of milk & Weak & + \\
\hline Starch hydrolysis & + & + \\
\hline Calcium malate solubilization & - & - \\
\hline Nitrite from nitrate & + & - \\
\hline \multicolumn{3}{|l|}{ Growth at: } \\
\hline $10{ }^{\circ} \mathrm{C}$ & - & - \\
\hline $15^{\circ} \mathrm{C}$ & - & + \\
\hline $20{ }^{\circ} \mathrm{C}$ & ++ & ++ \\
\hline $30^{\circ} \mathrm{C}$ & ++ & ++ \\
\hline $37^{\circ} \mathrm{C}$ & - & - \\
\hline \multicolumn{3}{|l|}{ Growth on: } \\
\hline $0 \% \mathrm{NaCl}$ & + & + \\
\hline $4 \% \mathrm{NaCl}$ & - & - \\
\hline
\end{tabular}

Table 2. Chemotaxonomic characteristics of isolates $\mathrm{R}-31^{\top}$ and $\mathrm{R}-55^{\mathrm{T}}$

\begin{tabular}{|lcc|}
\hline Characteristic & R-31 & R-55 $^{\mathbf{T}}$ \\
\hline Amino acid composition of peptidoglycan & & \\
Glutamic acid & $1 \cdot 00$ & $1 \cdot 00$ \\
Alanine & $1 \cdot 80$ & $2 \cdot 04$ \\
meso-Diaminopimelic acid & $1 \cdot 09$ & $0 \cdot 69$ \\
Sugar composition of whole cells $(\%): \dagger$ & \\
Rhamnose & $\mathrm{ND}$ & trace \\
Madurose & ++ & ++ \\
Galactose & + & + \\
Xylose & trace & trace \\
Glucose & ++ & ++ \\
Major menaquinone:t & & \\
$9\left(\mathrm{H}_{2}\right)$ & + & + \\
$9\left(\mathrm{H}_{4}\right)$ & ++ & ++ \\
$9\left(\mathrm{H}_{6}\right)$ & + & + \\
Phospholipid composition: & & \\
Phosphatidylglycerol & - & - \\
Unidentified phospholipid & + & + \\
including glucosamine & & \\
Phosphatidylcholine & - & - \\
Phosphatidylethanolamine & + & + \\
Phospholipid type & $\mathrm{IV}$ & $\mathrm{IV}$ \\
Mycolic acid & $\mathrm{ND}$ & $\mathrm{ND}$ \\
Acyl type of peptidoglycan & Acetyl & Acetyl \\
\hline
\end{tabular}

* Relative to glutamic acid as 1.0.

$\dagger$ Scored as ++ , major amount; + , minor amount; trace, trace amount.

+ Scored as,$++>20 \% ;+,<20 \%$.

ND, Not detected.

to rod-shaped $(0 \cdot 8-1.0 \times 1.0-1.5 \mu \mathrm{m})$ and had a smooth surface.

\section{Cultural characteristics}

Both strains exhibited good growth on oatmeal agar (ISP medium 3), moderate growth on inorganic salts/ starch agar (ISP medium 4) and poor growth on yeast extract/malt extract agar (ISP medium 2), peptone/ yeast extract iron agar (ISP medium 6), tyrosine agar (ISP medium 7) and nutrient agar. On glycerol/ asparagine agar (ISP medium 5), isolate R-31 ${ }^{\mathrm{T}}$ grew poorly and isolate R-55 ${ }^{\mathrm{T}}$ grew moderately. Colonies on most media tested were pale yellow. Only isolate $\mathrm{R}-55^{\mathrm{T}}$ sporulated on oatmeal agar (ISP medium 3 ). Neither isolate produced soluble pigment on any medium tested. Both isolates formed aerial hyphae and sporulated on HV agar (data not shown).

\section{Physiological and biochemical characteristics}

Biochemical properties of the isolates are shown in Table 1. Both isolates actuated starch hydrolysis but not gelatin liquefaction or calcium malate 
Table 3. Cellular fatty acid compositions of strains $\mathrm{R}-31^{\mathrm{T}}$ and $\mathrm{R}-55^{\mathrm{T}}$

Abundances of individual fatty acids are shown as percentages. ND, Not detected.

\begin{tabular}{|lcr|}
\hline Fatty acid & $\mathbf{R}^{-31^{\mathbf{T}}}$ & $\mathbf{R - 5 5}^{\mathbf{T}}$ \\
\hline Iso-branched fatty acids & & \\
$\mathrm{C}_{14: 0}$ & $12 \cdot 0$ & $8 \cdot 4$ \\
$\mathrm{C}_{16: 0}$ & $30 \cdot 4$ & $26 \cdot 1$ \\
Saturated fatty acids & & \\
$\mathrm{C}_{13: 0}$ & $1 \cdot 1$ & $1 \cdot 0$ \\
$\mathrm{C}_{14: 0}$ & $\mathrm{ND}$ & $1 \cdot 1$ \\
$\mathrm{C}_{15: 0}$ & $5 \cdot 4$ & $5 \cdot 8$ \\
$\mathrm{C}_{16: 0}$ & $3 \cdot 9$ & $5 \cdot 4$ \\
$\mathrm{C}_{17: 0}$ & $8 \cdot 4$ & $8 \cdot 1$ \\
$\mathrm{C}_{18: 0}$ & $1 \cdot 3$ & $1 \cdot 6$ \\
Unsaturated fatty acids $_{\mathrm{C}_{17: 1}}$ & & \\
$\mathrm{C}_{18: 1}$ & $6 \cdot 5$ & $6 \cdot 3$ \\
$10-$ Methylated fatty acids & $0 \cdot 7$ & $0 \cdot 9$ \\
$\mathrm{C}_{16: 0}$ & & \\
$\mathrm{C}_{17: 0}$ & $1 \cdot 2$ & $1 \cdot 9$ \\
$\mathrm{C}_{18: 0}$ & $27 \cdot 3$ & $27 \cdot 7$ \\
\hline
\end{tabular}

solubilization. Both utilized glucose, raffinose, rhamnose and D-mannitol, and isolate $\mathrm{R}-55^{\mathrm{T}}$ also utilized sucrose. Isolate $\mathrm{R}-31^{\mathrm{T}}$ reduced nitrate, but isolate $\mathrm{R}$ $55^{\mathrm{T}}$ did not. Both isolates grew well at 20 and $30^{\circ} \mathrm{C}$, but neither could grow at 10 or $37^{\circ} \mathrm{C}$. Neither isolate could grow on $4 \% \mathrm{NaCl}$.

\section{Chemotaxonomic characteristics}

The whole-cell sugar pattern, cell-wall amino acid composition, phospholipid type, menaquinone composition and cellular fatty acid composition of the isolates are shown in Tables 2 and 3. Their cell walls contained meso-diaminopimelic acid, D-glutamic acid and L-alanine, indicating that the peptidoglycan is type A1 $\gamma$, according to Schleifer \& Kandler (1972). The isolates contained madurose and glucose as the major whole-cell sugars in addition to small amounts of galactose and xylose, indicating that the whole-cell sugar pattern of these isolates is $\mathrm{B}$, according to Lechevalier \& Lechevalier (1970). The major menaquinone was MK-9 $\left(\mathrm{H}_{4}\right)$, and small amounts of MK$9\left(\mathrm{H}_{2}\right)$ and MK-9 $\left(\mathrm{H}_{6}\right)$ were present (Table 2). The isolates contained iso- $\mathrm{C}_{16: 0}$ and 10-methyl $\mathrm{C}_{17: 0}$ as the major cellular fatty acids, with small amounts of iso$\mathrm{C}_{14: 0}, \mathrm{C}_{17: 0}, \mathrm{C}_{17: 1}, \mathrm{C}_{15: 0}$ and $\mathrm{C}_{16: 0}$ (Table 3). Mycolic acids were absent. Phosphatidylethanolamine and an unidentified phospholipid including glucosamine were detected, but phosphatidylglycerol and phosphatidylcholine were not detected, corresponding to phospholipid type IV of Lechevalier et al. (1981). The acyl type of the cell wall polysaccharides was acetyl. The $\mathrm{G}+\mathrm{C}$ contents of DNA were $68.6 \mathrm{~mol} \%$ for isolate R-31 ${ }^{\mathrm{T}}$ and $68.1 \mathrm{~mol} \%$ for isolate R- $55^{\mathrm{T}}$.

\section{Phylogenetic analysis}

$16 \mathrm{~S}$ rDNA sequences were determined for $\mathrm{R}-31^{\mathrm{T}}$ (positions 28-1525 of the Escherichia coli numbering

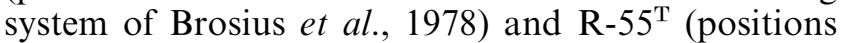
28-1519). Positions at which secondary structures varied between strains and positions at which sequences were not determined in some reference organisms were excluded from the analysis. The phylogenetic tree obtained by applying the neighbourjoining method to $K_{\text {nuc }}$ values is depicted in Fig. 3. The $16 \mathrm{~S}$ rDNA analysis revealed that the isolates fell in the cluster of the family Streptosporangiaceae. The isolates were closely related to $S$. corrugatum (similarity levels 97.6-98.8 \%), Herbidospora cretacea $(97 \cdot 2-97 \cdot 3 \%), S$. claviforme (96.9-97.5\%) and Planotetraspora mira $(96 \cdot 9-97 \cdot 1 \%)$. Binary similarity values of the $16 \mathrm{~S}$ rDNA between this cluster and other members of the family Streptosporangiaceae are 90.0-96.9\%.

\section{DNA-DNA hybridization}

The results of DNA-DNA hybridization among isolates R-31 ${ }^{\mathrm{T}}$ and R-55 ${ }^{\mathrm{T}}$, S. corrugatum IFO $13972^{\mathrm{T}}, H$. cretacea IFO $15474^{\mathrm{T}}, S$. claviforme IFO $15623^{\mathrm{T}}$ and $P$. mira IFO $15435^{\mathrm{T}}$ are shown in Table 4. Relatedness between the isolates was $45-49 \%$. The relatedness between the isolates and S. corrugatum IFO $13972^{\mathrm{T}}$ was $12-24 \%$. In contrast, low levels of relatedness (3-9\%) were found between these three strains and the other strains belonging to related species used for comparison.

\section{DISCUSSION}

Isolates $\mathrm{R}-31^{\mathrm{T}}$ and $\mathrm{R}-55^{\mathrm{T}}$ form club-shaped or spherical sporangia at the heads of the aerial mycelia and have meso-diaminopimelic acid as a cell-wall diamino acid, madurose in the whole-cell hydrolysate, MK$9\left(\mathrm{H}_{4}\right)$ as the major menaquinone and phospholipid type IV. The isolates produce spores by fragmentation of hyphae and the hyphal sheath, which either expands to form the sporangial envelope or remains around the spore chains. Although the morphological characteristics and spore development of isolates were similar in many respects to those of Streptosporangium species, there were differences in the irregular shape and variable size of spore vesicles. Under the light microscope, the isolates appeared similar to Nonomuraea pusilla, which develops pseudosporangia, rather than to the majority of Streptosporangium species. Similar morphological features are also shown by $S$. corrugatum. Williams \& Sharples (1976) reported that, as the club-shaped structures matured, partial or complete removal of their outer, wrinkled envelope revealed chains of three to eight spores, which were prominently ridged. Spores were $0 \cdot 8-1 \cdot 0 \mu \mathrm{m}$ in length and $0 \cdot 6-0.7 \mu \mathrm{m}$ in breadth. Ridges were mostly longi- 


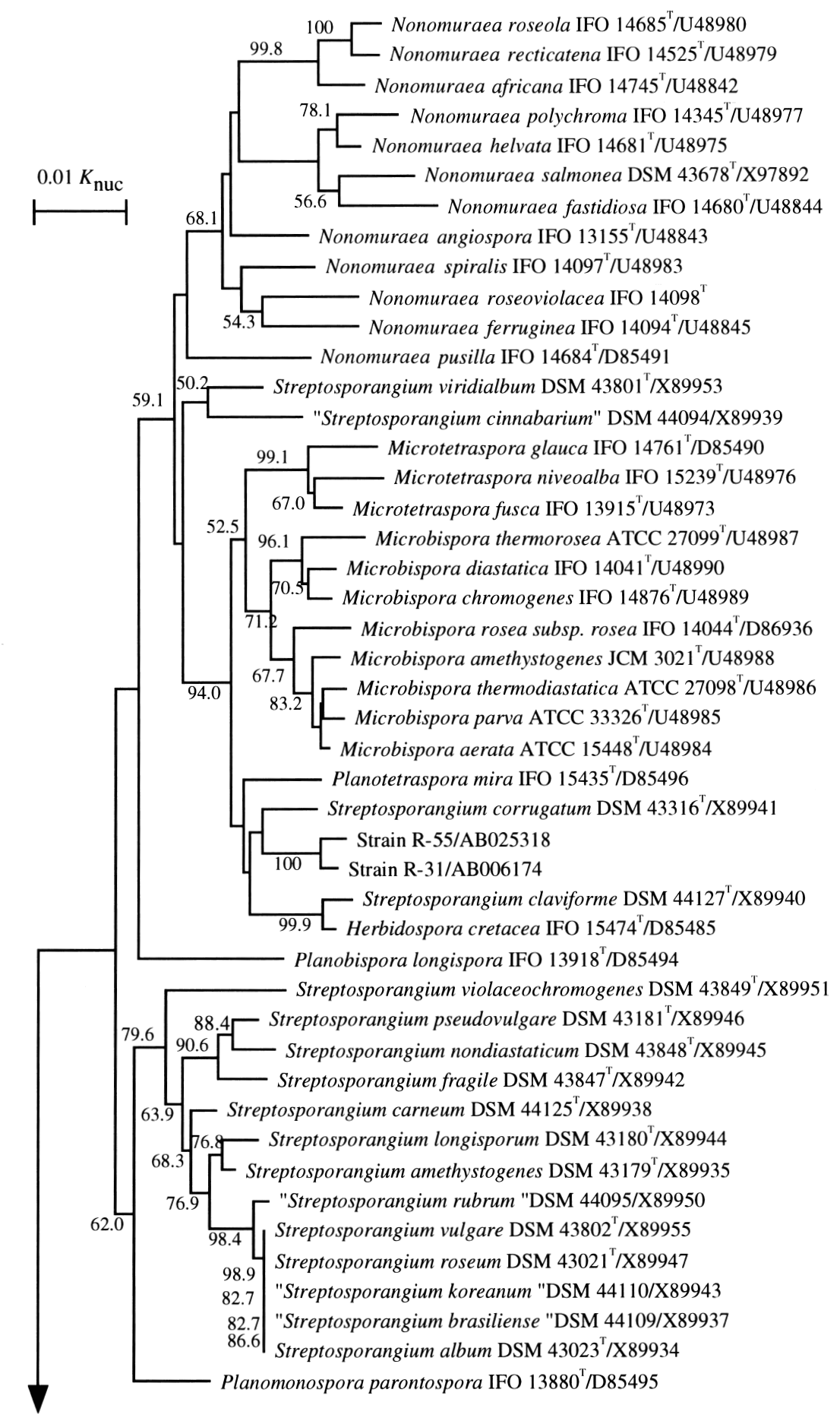

Streptomyces ambofaciens ATCC $23877^{\mathrm{T}} / \mathrm{M} 27245$

Fig. 3. Phylogenetic tree, based on neighbour-joining (Saitou \& Nei, 1987), derived from 16S rRNA sequences for members of the family Streptosporangiaceae. Streptomyces ambofaciens ATCC $23877^{\top}$ (M27245) was used as the root organism. Bar, $0.01 K_{\text {nuc }}$ in nucleotide sequences. The numbers on the branches are confidence limits (expressed as percentages) estimated from a bootstrap analysis with 1000 replicates (only percentages above $50 \%$ are indicated).

tudinal, with annular ridges between adjacent spores. These spores, therefore, had the same form as those found inside the spherical bodies. Although the surfaces of the spherical bodies were smooth at first, they became wrinkled or remained around the spore chains as spores developed. 
Table 4. DNA association between isolates $R-31^{\top}$ and $R-55^{\top}$ and related strains

The data are percentage DNA-DNA reassociation values between DNA of the taxa shown.

\begin{tabular}{|lcccccc|}
\hline Taxon & $\mathbf{1}$ & $\mathbf{2}$ & $\mathbf{3}$ & $\mathbf{4}$ & $\mathbf{5}$ & $\mathbf{6}$ \\
\hline 1. Isolate R-31 $^{\mathrm{T}}$ & 100 & $45 \pm 18$ & $12 \pm 4$ & $8 \pm 1$ & $3 \pm 1$ & $6 \pm 1$ \\
2. Isolate R-55 & $49 \pm 11$ & 100 & $17 \pm 5$ & $6 \pm 1$ & $4 \pm 1$ & $7 \pm 2$ \\
3. Streptosporangium corrugatum IFO $13972^{\mathrm{T}}$ & $17 \pm 6$ & $24 \pm 3$ & 100 & $6 \pm 1$ & $5 \pm 2$ & $7 \pm 1$ \\
4. Planotetraspora mira IFO 15435 & $2 \pm 1$ & $3 \pm 0$ & $3 \pm 1$ & 100 & $3 \pm 1$ & $2 \pm 0$ \\
5. Herbidospora cretacea IFO 15474 & $5 \pm 1$ & $6 \pm 0$ & $9 \pm 1$ & $5 \pm 0$ & 100 & $80 \pm 17$ \\
6. Streptosporangium claviforme IFO 15623 & $6 \pm 1$ & $6 \pm 1$ & $7 \pm 3$ & $4 \pm 1$ & $80 \pm 6$ & 100 \\
\hline
\end{tabular}

Table 5. Morphological features and chemotaxonomic characteristics of the new taxon (isolates $\mathrm{R}-31^{\top}$ and $\mathrm{R}-55^{\top}$ and S. corrugatum) and the family Streptosporangiaceae

\begin{tabular}{|c|c|c|c|c|c|c|c|c|c|}
\hline Characteristic & New taxon & Herbidospora & Planotetraspora & $\begin{array}{c}\text { Strepto- } \\
\text { sporangium }\end{array}$ & Microtetraspora & Nonomuraea & Microbispora & Planomonospora & Planobispora \\
\hline $\begin{array}{l}\text { Sporangium } \\
\text { formation }\end{array}$ & $\begin{array}{c}\text { Club or globose } \\
\text { sporangia on aerial } \\
\text { mycelium }\end{array}$ & $\begin{array}{l}\text { Spore chains on } \\
\text { sporophore }\end{array}$ & $\begin{array}{c}\text { Sporangia, } \\
\text { containing quartet } \\
\text { of } \\
\text { spores }\end{array}$ & $\begin{array}{l}\text { Globose sporangia } \\
\text { on aerial } \\
\text { mycelium }\end{array}$ & $\begin{array}{l}\text { Spore chains, } \\
\text { typically } \\
\text { containing four } \\
\text { spores on short } \\
\text { aerial mycelium }\end{array}$ & $\begin{array}{c}\text { Spore chain or } \\
\text { pseudosporangium } \\
\text { on aerial mycelium }\end{array}$ & $\begin{array}{c}\text { Spores in } \\
\text { characteristic } \\
\text { longitudinal } \\
\text { pairs on aerial } \\
\text { mycelium }\end{array}$ & $\begin{array}{l}\text { Cylindrical to } \\
\text { clavate sporangia, } \\
\text { containing a } \\
\text { single spore }\end{array}$ & $\begin{array}{l}\text { Cylindrical to } \\
\text { clavate sporangia, } \\
\text { containing } \\
\text { longitudinal pair } \\
\text { of spores }\end{array}$ \\
\hline Cell-wall type & III & III & III & III & III & III & III & III & III \\
\hline $\begin{array}{l}\text { Whole-cell sugar } \\
\text { pattern }\end{array}$ & $\mathrm{B}, \mathrm{C}$ & B & $\mathrm{D}, \mathrm{A}$ & B & $\mathrm{B}, \mathrm{C}$ & $\mathrm{B}, \mathrm{C}$ & $\mathrm{B}, \mathrm{C}$ & B & B \\
\hline Fatty-acid type & $3 \mathrm{c}$ & $3 \mathrm{c}$ & NT & $3 c$ & $3 \mathrm{c}$ & $3 \mathrm{c}$ & $3 c$ & $3 \mathrm{c}$ & $3 \mathrm{c}$ \\
\hline $\begin{array}{l}\text { Major } \\
\text { menaquinone }\end{array}$ & $\begin{array}{c}\text { MK-9 } \\
\left(\mathrm{H}_{2}, \mathrm{H}_{4}, \mathrm{H}_{6}\right)\end{array}$ & $\begin{array}{c}\text { MK-10 } \\
\left(\mathrm{H}_{4}, \mathrm{H}_{6}, \mathrm{H}_{2}\right)\end{array}$ & NT & $\begin{array}{c}\text { MK-9 } \\
\left(\mathrm{H}_{2}, \mathrm{H}_{4}\right)\end{array}$ & $\begin{array}{c}\text { MK-9 } \\
\left(\mathrm{H}_{0}, \mathrm{H}_{2}, \mathrm{H}_{4}\right)\end{array}$ & $\begin{array}{c}\text { MK-9 } \\
\left(\mathrm{H}_{0}, \mathrm{H}_{2}, \mathrm{H}_{4}\right)\end{array}$ & $\begin{array}{c}\text { MK-9 } \\
\left(\mathrm{H}_{6}, \mathrm{H}_{2}, \mathrm{H} 4\right)\end{array}$ & $\begin{array}{c}\text { MK-9 } \\
\left(\mathrm{H}_{2}\right)\end{array}$ & $\begin{array}{c}\text { MK-9 } \\
\left(\mathrm{H}_{2}, \mathrm{H}_{4}\right)\end{array}$ \\
\hline Phospholipid type & IV, II & IV & NT & IV & IV & IV & IV & IV & IV \\
\hline
\end{tabular}

NT, Not tested.

The phylogenetic position of the isolates is within the confines of the family Streptosporangiaceae, adjacent to $S$. corrugatum, which occupies a phylogenetic position distinct from other species of Streptosporangium (Kemmerling et al., 1993; Ward-Rainey et al., 1996).

S. corrugatum was reported as a species with some unusual morphological features (Williams \& Sharples, 1976): it possesses the major menaquinones $\mathrm{MK}-9\left(\mathrm{H}_{2}\right)$ and MK-9 $\left(\mathrm{H}_{4}\right)$ (Kudo \& Seino, 1987; Collins et al., 1988; Stackebrandt et al., 1994), major fatty acids $\mathrm{C}_{17: 1}$ and $\mathrm{C}_{17: 0}$ (Kudo \& Seino, 1987; Stackebrandt et al., 1994) and galactose and a trace amount of madurose as whole-cell sugars (Stackebrandt et al., 1994). It contains phosphatidylethanolamine but not ninhydrin-positive or sugar-positive phospholipids (Stackebrandt et al., 1994), indicating that the phospholipid type is II, according to Lechevalier et al. (1981). Isolates $\mathrm{R}-31^{\mathrm{T}}$ and $\mathrm{R}-55^{\mathrm{T}}$, on the other hand, contained phosphatidylethanolamine and ninhydrinpositive and sugar-positive phospholipids, indicating that the phospholipid type is IV (Lechevalier et al., 1981). Some chemotaxonomic characteristics of the isolates and $S$. corrugatum were therefore different. However, the results of morphological observation and phylogenetic analysis indicate that they belong to the same group.
Isolates $\mathrm{R}-31^{\mathrm{T}}$ and $\mathrm{R}-55^{\mathrm{T}}, S$. corrugatum, H. cretacea, $S$. claviforme and $P$. mira appear to be closely related to each other, as shown by $16 \mathrm{~S}$ rDNA sequence similarities ranging from 96.9 to $98.8 \%$. However, the isolates are distinguished from the genus Herbidospora in their morphological features and major menaquinone and from the genus Planotetraspora in their morphological features and sugar composition (Table 5). Both morphological features and chemotaxonomic characteristics indicate that they are distinct from known actinomycetes belonging to the family Streptosporangiaceae (Table 5).

On the basis of their morphological characteristics and our phylogenetic analysis, isolates $\mathrm{R}-31^{\mathrm{T}}$ and $\mathrm{R}-55^{\mathrm{T}}$ are readily distinguishable from the actinomycetes mentioned above and warrant the creation of a new taxon. Therefore, we propose the classification of these isolates and $S$. corrugatum in the new genus Acrocarpospora gen. nov., with Acrocarpospora pleiomorpha sp. nov. for isolate $\mathrm{R}-31^{\mathrm{T}}$, Acrocarpospora macrocephala sp. nov. for isolate $\mathrm{R}-55^{\mathrm{T}}$ and Acrocarpospora corrugata comb. nov. for $S$. corrugatum. These strains have been deposited in the Institute for Fermentation, Osaka, as strains IFO $16267^{\mathrm{T}}(A$. pleiomorpha $\left.\mathrm{R}-31^{\mathrm{T}}\right)$, IFO $16266^{\mathrm{T}}$ (A. macrocephala $\mathrm{R}-55^{\mathrm{T}}$ ) and IFO $13972^{\mathrm{T}}$ (A. corrugata). Table 5 summarizes the differential characteristics of the new 
genus and other members of the family Streptosporangiaceae.

The morphological features of $S$. claviforme are similar to those of $H$. cretacea. Furthermore, their high DNA relatedness $(80 \%)$ indicates that $S$. claviforme is a subjective synonym of $H$. cretacea. The taxonomic position of $S$. viridialbum remains ambiguous.

\section{Description of Acrocarpospora gen. nov.}

Acrocarpospora (A.cro.car.po.spo'ra. Gr. adj. Akros pointed, sharp, highest; Gr. n. karpos fruit, harvest; Gr. fem. n. spora a seed; M.L. fem. n. Acrocarpospora an organism forming spores like fruits on the terminal mycelium).

Cells are Gram-positive and non-acid-fast and organisms form branching hyphae. Non-fragmentary substrate mycelia are present. Spherical and clubshaped structures are borne on the tips of the aerial mycelium. These structures contain coiled spore chains. Spores are oval or short rod-like $(0 \cdot 6-$ $0.8 \times 0.7-1.0 \mu \mathrm{m})$ with a smooth surface and nonmotile.

Strictly aerobic. Good growth occurs between 20 and $30{ }^{\circ} \mathrm{C}$. The organism shows good growth on oatmeal agar. In general, the vegetative mycelia are pale yellow and aerial hyphae are white.

Cell walls contain glutamic acid, alanine and meso-diaminopimelic acid. Wall chemotype is III (Lechevalier \& Lechevalier, 1970) and the peptidoglycan type is presumed to be A1 $\gamma$ (Schleifer \& Kandler, 1972). Madurose, glucose and galactose are detected in whole-cell sugars. Major cellular fatty acids are iso- $\mathrm{C}_{16: 0}, 10$-methyl $\mathrm{C}_{17: 0}, \mathrm{C}_{17: 1}$ and $\mathrm{C}_{17: 0}$. The $\mathrm{G}+\mathrm{C}$ content of DNA is $68-69 \mathrm{~mol} \%$. The major menaquinones are MK-9 $\left(\mathrm{H}_{4}\right)$ and $\mathrm{MK}-9\left(\mathrm{H}_{2}\right)$ and small amounts of MK-9 $\left(\mathrm{H}_{6}\right)$ are present. Phosphatidylethanolamine is present as a diagnostic phospholipid. Mycolic acids are absent. The acyl type of cell-wall polysaccharide is acetyl. The type species is Acrocarpospora pleiomorpha.

\section{Description of Acrocarpospora pleiomorpha sp. nov.}

Acrocarpospora pleiomorpha (ple.i.o.mor'pha. Gr. adj. pleion more; Gr. n. morphe form; M.L. fem. adj. pleiomorpha pleiomorphic, in various shapes).

Morphological, chemotaxonomic and general characteristics are as given above for the genus. Gelatin liquefaction is negative. Hydrolyses starch. Does not decompose calcium malate. Coagulation of milk is weak. Reduction of nitrate is positive. Glucose, raffinose, rhamnose and mannitol are utilized, but xylose, arabinose, sucrose, fructose and inositol are not. As diagnostic phospholipids, phosphatidylethanolamine, ninhydrin-positive and sugar-positive phospholipids are present. The $\mathrm{G}+\mathrm{C}$ content of DNA is $69 \mathrm{~mol} \%$. Habitat is soil. The type strain is $\mathrm{R}-31^{\mathrm{T}}$ $\left(=\mathrm{IFO} 16267^{\mathrm{T}}\right)$.
Description of Acrocarpospora macrocephala sp. nov.

Acrocarpospora macrocephala (ma.cro.ce'pha.la. Gr. adj. makros large; Gr. fem. n. kephale head; M.L. fem. nom. n. macrocephala large head).

Morphological, chemotaxonomic and general characteristics are as given above for the genus. Gelatin liquefaction is negative. Hydrolyses starch. Does not decompose calcium malate. Coagulates milk. Glucose, raffinose, rhamnose, mannitol and sucrose are utilized, but xylose, arabinose, fructose and inositol are not. As diagnostic phospholipids, phosphatidylethanolamine and ninhydrin-positive and sugar-positive phospholipids are present. The $\mathrm{G}+\mathrm{C}$ content of DNA is 68 $\mathrm{mol} \%$. Habitat is soil. The type strain is $\mathrm{R}-55^{\mathrm{T}}$ ( $=\mathrm{IFO}$ $\left.16266^{\mathrm{T}}\right)$.

\section{Description of Acrocarpospora corrugata (Williams and Sharples 1976) comb. nov.}

Acrocarpospora corrugata (cor.ru.ga'ta. L. fem. adj. corrugata wrinkled).

Descriptions of this taxon have been published previously by Williams \& Sharples (1976), Stackebrandt et al. (1994), Kudo \& Seino (1987), Collins et al. (1988) and Whitham et al. (1993). As diagnostic phospholipids, phosphatidylethanolamine is present, but ninhydrin-positive and sugar-positive phospholipids are absent. The type strain is IFO $13972^{\mathrm{T}}$.

\section{ACKNOWLEDGEMENTS}

We thank Professor Dr Hans G. Trüper, Institut für Mikrobiologie und Biotechnologie, Rheinische FriedrichWilhelms-Universität Bonn, for help with the Latin names.

\section{REFERENCES}

Brosius, J., Palmer, M. L., Kennedy, P. J. \& Noller, H. F. (1978). Complete nucleotide sequence of a $16 \mathrm{~S}$ ribosomal RNA gene from Escherichia coli. Proc Natl Acad Sci USA 75, 4801-4805.

Collins, M. D., Kroppenstedt, R. M., Tamaoka, J., Komagata, K. \& Kinoshita, T. (1988). Structures of the tetrahydrogenated menaquinones from Actinomadura angiospora, Faenia rectivirgula, and Saccharothrix australiensis. Curr Microbiol 17, 275-279.

Ezaki, T., Hashimoto, Y., Takeuchi, N., Yamamoto, H., Liu, S.-L., Miura, H., Matsui, K. \& Yabuuchi, E. (1988). Simple genetic method to identify viridans group streptococci by colorimetric dot hybridization and fluorometric hybridization in microdilution wells. J Clin Microbiol 26, 1708-1713.

Ezaki, T., Hashimoto, Y. \& Yabuuchi, E. (1989). Fluorometric deoxyribonucleic acid-deoxyribonucleic acid hybridization in microdilution wells as an alternative to membrane filter hybridization in which radioisotopes are used to determine genetic relatedness among bacterial strains. Int J Syst Bacteriol 39, 224-229.

Felsenstein, J. (1985). Confidence limits on phylogenies: an approach using the bootstrap. Evolution 39, 783-791.

Furumai, T., Ogawa, H. \& Okuda, T. (1968). Taxonomic study on Streptosporangium albidum nov. sp. J Antibiot 21, 179-181. 
Kemmerling, C., Gürtler, H., Kroppenstedt, R. T., Toalster, R. \& Stackebrandt, E. (1993). Evidence for the phylogenetic heterogeneity of the genus Streptosporangium. Syst Appl Microbiol 16, 369-372.

Kimura, M. (1980). A simple method for estimating evolutionary rates of base substitutions through comparative studies of nucleotide sequences. J Mol Evol 16, 111-120.

Kudo, T. \& Seino, A. (1987). Transfer of Streptosporangium indianense Gupta 1965 to the genus Streptomyces as Streptomyces indiaensis (Gupta 1965) comb. nov. Int J Syst Bacteriol 37, 241-244.

Kudo, T., Itoh, T., Miyadoh, S., Shomura, T. \& Seino, A. (1993). Herbidospora gen. nov., a new genus of the family Streptosporangiaceae Goodfellow et al. 1990. Int J Syst Bacteriol 43, 319-328.

Lechevalier, M. P. \& Lechevalier, H. A. (1970). Chemical composition as a criterion in the classification of aerobic actinomycetes. Int $J$ Syst Bacteriol 20, 435-443.

Lechevalier, M. P., Stern, A. E. \& Lechevalier, H. A. (1981). Phospholipids in the taxonomy of actinomycetes. Zentralbl Bakteriol Parasitenkd Infektionskr Hyg I Abt Suppl 11, 111-116.

Mesbah, M., Premachandran, U. \& Whitman, W. B. (1989). Precise measurement of the $\mathrm{G}+\mathrm{C}$ content of deoxyribonucleic acid by high-performance liquid chromatography. Int $J$ Syst Bacteriol 39, 159-167.

Nonomura, H. \& Ohara, Y. (1960). Distribution of the actinomycetes in soil. V. The isolation and classification of the genus Streptosporangium. J Ferment Technol 38, 405-409.

Nonomura, H. \& Ohara, Y. (1969). Distribution of actinomycetes in soil. VII. A culture method effective for both of preferential isolation and enumeration of Microbispora and Streptosporangium strains in soil. Part 2. Classification of the isolates. J Ferment Technol 47, 701-709.

Ochi, K. \& Miyadoh, S. (1992). Polyacrylamide gel electrophoresis analysis of ribosomal protein AT-L30 from an actinomycete genus, Streptosporangium. Int J Syst Bacteriol 42, 151-155.

Okuda, T., Furumai, T., Watanabe, E., Okugawa, Y. \& Kimura, S. (1966). Actinoplanaceae antibiotics. II. Studies of sporaviridin. Taxonomic study on the sporaviridin-producing microorganism, Streptosporangium viridogriseum nov. sp. J Antibiot 19, 121-127.

Pernodet, J.-L., Boccard, F., Alegre, M.-T., Gagnat, J. \& Guérineau, M. (1989). Organization and nucleotide sequence analysis of a ribosomal RNA gene cluster from Streptomyces ambofaciens. Gene 79, 33-46.

Perrière, G. \& Gouy, M. (1996). WWW-query: an on-line retrieval system for biological sequence banks. Biochimie $\mathbf{7 8}$, 364-369.

Petrolini, B., Quaroni, S., Sardi, P., Saracchi, M. \& Andriollo, N. (1992). A sporangiate actinomycete with unusual morphological features: Streptosporangium claviforme sp. nov. Actinomycetes 3, 45-50.

Rayner, R. W. (1970). A Mycological Colour Chart. Kew: Commonwealth Mycological Institute \& British Mycological Society.

Runmao, H., Guizhen, W. \& Junying, L. (1993). A new genus of actinomycetes, Planotetraspora gen. nov. Int J Syst Bacteriol 43, 468-470.

Saiki, R. K., Gelfand, D. H., Stoffel, S., Scharf, S. J., Higuchi, R., Horn, G. T., Mullis, K. B. \& Erlich, H. A. (1988). Primer-directed enzymatic amplification of DNA with a thermostable DNA polymerase. Science 239, 487-491.

Saito, H. \& Miura, K. (1963). Preparation of transforming deoxyribonucleic acid by phenol treatment. Biochim Biophys Acta 72, 619-629.

Saitou, N. \& Nei, M. (1987). The neighbor-joining method: a new method for reconstructing phylogenetic trees. Mol Biol Evol 4, 406-425.

Schleifer, K.-H. \& Kandler, O. (1972). Peptidoglycan types of bacterial cell walls and their taxonomic implications. Bacteriol Rev 36, 407-477.

Shirling, E. B. \& Gottlieb, D. (1966). Methods for characterization of Streptomyces species. Int J Syst Bacteriol 16, 313-340.

Stackebrandt, E., Kroppenstedt, R. M., Jahnke, K.-D., Kemmerling, C. \& Gürtler, H. (1994). Transfer of Streptosporangium viridogriseum (Okuda et al. 1996), Streptosporangium viridogriseum subsp. kofuense (Nonomura and Ohara 1969), and Streptosporangium albidum (Furumai et al. 1968) to Kutzneria gen. nov. as Kutzneria viridogrisea comb. nov., Kutzneria kofuensis comb. nov., and Kutzneria albida comb. nov., and emendation of the genus Streptosporangium. Int J Syst Bacteriol 44, 265-269.

Stackebrandt, E., Rainey, F. A. \& Ward-Rainey, N. L. (1997). Proposal for a new hierarchic classification system, Actinobacteria classis nov. Int J Syst Bacteriol 47, 479-491.

Tamura, T., Nakagaito, Y., Nishii, T., Hasegawa, T., Stackebrandt, E. \& Yokota, A. (1994). A new genus of the order Actinomycetales, Couchioplanes gen. nov., with descriptions of Couchioplanes caeruleus (Horan and Brodsky 1986) comb. nov. and Couchioplanes caeruleus subsp. azureus subsp. nov. Int $J$ Syst Bacteriol 44, 193-203.

Tamura, T., Hayakawa, M. \& Hatano, K. (1998). A new genus of the order Actinomycetales, Cryptosporangium gen. nov., with descriptions of Cryptosporangium arvum sp. nov. and Cryptosporangium japonicum sp. nov. Int J Syst Bacteriol 48, 995-1005.

Tamura, T., Hayakawa, M. \& Hatano, K. (1999). Sporichthya brevicatena sp. nov. Int J Syst Bacteriol 49, 1779-1784.

Thiemann, J. E. \& Beretta, G. (1968). A new genus of the Actinoplanaceae: Planobispora, gen. nov. Arch Mikrobiol 62, 157-166.

Thiemann, J. E., Pagani, H. \& Beretta, G. (1967). A new genus of the Actinoplanaceae: Planomonospora gen. nov. G Microbiol 15, 27-38.

Thompson, J. D., Higgins, D. G. \& Gibson, T. J. (1994). CLUSTAL W: improving the sensitivity of progressive multiple sequence alignment through sequence weighting, position-specific gap penalties and weight matrix choice. Nucleic Acids Res 22, 4673-4680.

Ward-Rainey, N., Rainey, F. A. \& Stackebrandt, E. (1996). The phylogenetic structure of the genus Streptosporangium. Syst Appl Microbiol 19, 50-55.

Whitham, T. S., Athalye, M., Minnikin, D. E. \& Goodfellow, M. (1993). Numerical and chemical classification of Streptosporangium and some related actinomycetes. Antonie Leeuwenhoek 64, 387-429.

Williams, S. T. \& Sharples, G. P. (1976). Streptosporangium corrugatum sp. nov., an actinomycete with some unusual morphological features. Int J Syst Bacteriol 26, 45-52.

Zhang, Z., Wang, Y. \& Ruan, J. (1998). Reclassification of Thermomonospora and Microtetraspora. Int J Syst Bacteriol 48, 411-422. 